\title{
Horizontal Single Axis Solar Tracker Using Arduino Approach
}

\author{
Siti Amely Jumaat, Adam Afiq Azlan Tan, Mohd Noor Abdullah, Nur Hanis Radzi, \\ Rohaiza Hamdan, Suriana Salimin, Muhammad Nafis bin Ismail \\ Faculty of Electrical and Electronic Engineering, Universiti Tun Hussein Onn Malaysia (UTHM), \\ 86400 Parit Raja, Batu Pahat, Johor, Malaysia
}

\begin{tabular}{l} 
Article Info \\
\hline Article history: \\
Received May 24, 2018 \\
Revised Jul 25, 2018 \\
Accepted Aug 3, 2018 \\
\hline
\end{tabular}

Keywords:

Arduino UNO

Light dependent resistor (LDR)

Servo motor

Solar tracker

\begin{abstract}
This project discusses on the development of horizontal single axis solar tracker using Arduino UNO which is cheaper, less complex and can still achieved the required efficiency. For the development of horizontal single axis solar tracking system, five light dependent resistors (LDR) has been used for sunlight detection and to capture the maximum light intensity. A servo motor is used to rotate the solar panel to the maximum light source sensing by the light dependent resistor (LDR) in order to increase the efficiency of the solar panel and generate the maximum energy. The efficiency of the system has been tested and compared with the static solar panel on several time intervals. A small prototype of horizontal single axis solar tracking system will be constructed to implement the design methodology presented here. As a result of solar tracking system, solar panel will generate more power, voltage, current value and higher efficiency.
\end{abstract}

Copyright $@ 2018$ Institute of Advanced Engineering and Science. All rights reserved.

\section{Corresponding Author:}

Siti Amely Jumaat,

Faculty of Electrical and Electronic Engineering,

Universiti Tun Hussein Onn Malaysia (UTHM),

86400 Parit Raja, Batu Pahat, Johor, Malaysia.

Email: amely@uthm.edu.my

\section{INTRODUCTION}

In this globalization era, demand of electricity keeps on increasing year by year [1]. The demanding of electricity gives an impact on the loss of main resources to produce electrical energy. Mankind have explored more ways and technologies for the production of electrical energy using the renewable energy resources. Renewable energy is an energy which generate from natural resources which are naturally replenished. Among all the renewable energy resources that have been discovered, solar energy is the most suitable. The solar energy provides light, heat and energy to all living things. Solar energy is a free energy which does not have any price if using it. Furthermore, solar energy does not produce any pollution, environmental friendly and endless supplies. Solar energy is an energy generated by the sun in the form of solar radiation. Solar radiation from the sun is collected and absorbed by the solar panels and convert into electrical energy. Solar energy shows a great potential for conversion into electrical in Malaysia because it has very high radiation levels.

Despite of solar energy being a good source of energy, there is a need to improve the methods to harness this energy. This can be achieved by using solar tracking system instead of fixed system. This report presented by (Oloka Reagan Otieno et. al., 2015) [2] come out with an idea to develop a single axis solar tracker for solar panel. The circuit is controlled by microcontroller Atmega328P, two dependent resistor (LDR) and a servo motor. The purpose of the research is to observe comparison of voltage reading between fixed and tracking solar panel. This paper presented by (Ayushi Nitin Ingole et. al., 2016) [3] proposed dual axis tracking method. Solar panel assemble and connected to a stepper motor to track the sun so that 
maximum sunlight will be directly shine on the panel at any given time of the day and year. This paper presented by (Tiberiu Tudorache, Liviu Kreindler et. al.) [4] deals with the design and execution of a solar tracker system dedicated to the PV conversion panels using a single axis solar tracker device to ensures the optimization of the conversion of solar energy into electricity by properly move and turn the PV panel into the real position of the sunlight. This paper by (Gagari Deb and Arijit Bardhan Roy et. al.) [5] discuss on the important of using solar tracking system for extracting solar energy. The researcher discussed on mechanism of building an efficient solar tracking system with the help of LabVIEW software. This thesis by (Muhammad Sami Sabry et. al., 2013) [6] discussed on determining the accuracy of solar trackers by measuring the tracker angles. The tracker angles of the the solar trackers were measured under varying conditions. It examines the degree to which the solar tracking system were able to achieve optimal solar angles (optimal accuracy) over the course of a day and under different operating conditions. (Md. Hanif Ali Sohag, Hasan, Khatun \& Ahmad et. al., 2015) [7] proposed the mechanism of solar tracking which was implemented by the use of an image processing software which combines the effect of sensors and processed image of sun to control the solar panel accordingly.

The purposes of this research are to develop a tracking system that control and monitor the movement of solar panel based on the intensity of the light, to measure output voltage, current and power, $\mathrm{P}=\mathrm{IV}$ and to compare the efficiency increase of a solar system between fixed solar system and solar tracking system.

\section{RESEARCH METHOD}

This section will be focusing on the methods used to develop horizontal single axis solar tracker using Arduino approach. It is divided into three sub-section which include the specification of components, software design and hardware design.

\subsection{Specification of Components}

This section discusses the components that used on this research.

\subsubsection{Arduino UNO}

The Arduino UNO is a micro-controller board based on the ATmega328 as shown in Figure 1.

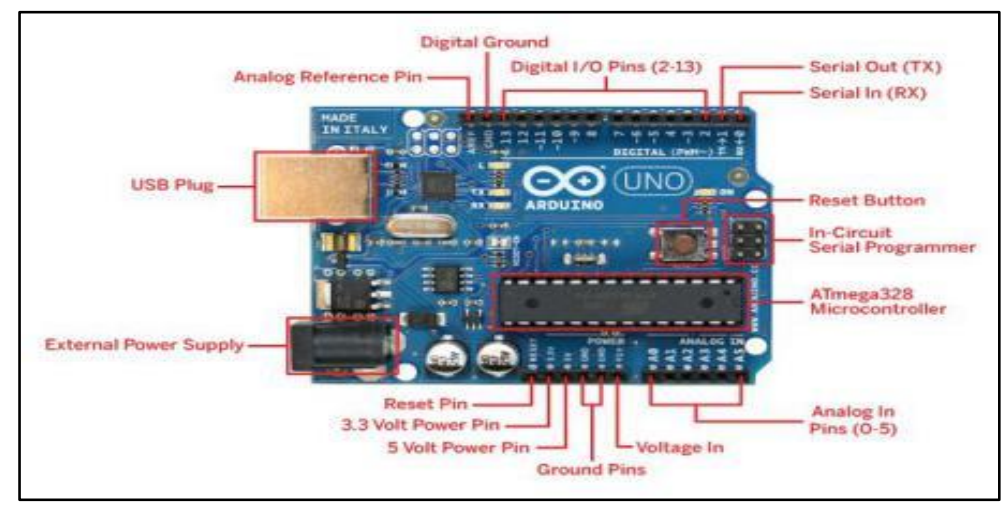

Figure 1. Arduino UNO

It has fourteen digital input/output pins (of which six of it can be used as PWM outputs), six analog inputs, a $16 \mathrm{MHz}$ crystal oscillator, a USB connection, a power jack, an ICSP header, and a reset button. It contains everything needed to support the micro-controller; it can simply connect to a computer with a USB cable or power it with a AC-to-DC adapter or battery to get started. The specifications of Arduino UNO are tabulated in the Table 1 [8], [9].

\subsubsection{Liquid Crystal Display (LCD)}

Liquid Crystal Display (LCD) is an electronic display module or screen and has a wide range of applications. It is very basic and very commonly used in many devices and circuits. LCD can display sixteen characters per line and a second line on the screen $(16 \times 2)$. The LCD will be displayed in a matrix of $5 \times 7$ pixels. The specifications of LCD display pins is tabulated in the Table 2. 
Table 1. Specifications of Arduino UNO

\begin{tabular}{|l|c|}
\hline Microcontroller & ATmega328P \\
\hline Operating Voltage & $5 \mathrm{~V}$ \\
\hline $\begin{array}{l}\text { Input Voltage } \\
\text { (recommended) }\end{array}$ & $7-12 \mathrm{~V}$ \\
\hline Digital I/O Pins & 14 \\
\hline PWM Digital Pins & 6 \\
\hline Analog Input Pins & 6 \\
\hline $\begin{array}{l}\text { DC Current per I/O } \\
\text { Pin }\end{array}$ & $20 \mathrm{~mA}$ \\
\hline DC Current for 3.3V \\
Pin & $50 \mathrm{~mA}$ \\
\hline Flash Memory & \\
\hline SRAM & $2 \mathrm{~KB}$ \\
\hline EEPROM & $1 \mathrm{~KB}$ \\
\hline Clock Speed & $16 \mathrm{MHz}$ \\
\hline Length & $68.6 \mathrm{~mm}$ \\
\hline Width & $53.4 \mathrm{~mm}$ \\
\hline Weight & $25 \mathrm{~g}$ \\
\hline
\end{tabular}

Table 2. Specifications of LCD Pins

\begin{tabular}{|c|c|c|}
\hline Pin No. & Pin Type and Name & Pin Description \\
\hline 1 & Source Pin/ GND/V $\mathrm{ss}$ & LCD ground pin \\
\hline 2 & Source Pin / Voc/Vdd & LCD supply voltage pin 5V \\
\hline 3 & Control Pin / V0/VEE & $\begin{array}{c}\text { To adjust the contrast of LCD } \\
\text { through variable resistor }\end{array}$ \\
\hline 4 & Control Pin / Register Select(RS) & $\begin{array}{c}\text { Select commend register when } \\
\text { low, and data register when } \\
\text { high }\end{array}$ \\
\hline 5 & Control Pin / Read/Write(R/W) & $\begin{array}{c}\text { Write register when low, read } \\
\text { register when high }\end{array}$ \\
\hline 6 & Control Pin / Enable(EN) & $\begin{array}{c}\text { Send data to data pins when } \\
\text { high to low pulse is given }\end{array}$ \\
\hline $7-14$ & Data/Command Pin / D1-D7 & $\begin{array}{c}\text { 8-bit data pins. Used to send } \\
\text { command or data to the LCD }\end{array}$ \\
\hline 15 & LED Pin / Anode & Backlight supply pin (5V) \\
\hline 16 & LED Pin / Cathode & Backlight ground pin (0V) \\
\hline
\end{tabular}

\subsubsection{Servo Motor}

A servo motor can be operated with power supply from $4.8 \mathrm{~V}$ to $6 \mathrm{~V}$. Normally voltage of $5 \mathrm{~V}$ with operating frequency, $\mathrm{f}_{0}=40 \mathrm{~Hz}$ is used. Servo motor is used to give accurate angle control such as 45 degrees, 90 degrees. The angle can be hold continuously. It can rotate from 0 degree to 180 degrees when the pulse duty ration changed.

\subsubsection{Light Dependent Resistor (LDR)}

A light dependent resistor is made from semiconductor materials which enable them to have their light sensitive properties. Light dependent resistor is very sensitive towards light. The resistance of light dependent resistor may change over many order when light shine on it. Significance value of the resistance falling as the level of light shine on the light dependent resistor increases.

\subsubsection{Solar Cells}

A solar cell or photo-voltaic cell is an electrical device that converts the energy of light from the sun into electricity by the photo-voltaic effect, which is a physical and chemical phenomenon. Solar cell is a device whose electrical characteristics such as current, voltage and resistance vary when exposed to the sunlight. Poly-crystalline solar cells as shown in Figure 2 is used in this research. The specifications of polycrystalline is shown in the Table 3. 


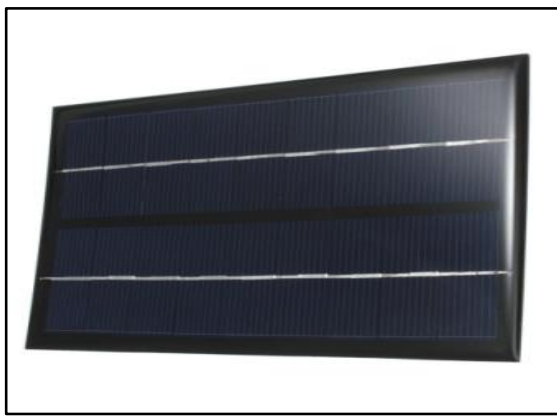

Figure 2. Poly-crystalline Solar Cell
Table 3. Specifications of Poly-crystalline

\begin{tabular}{|l|c|}
\hline Type & 3W 9V solar panel \\
\hline Solar Cell & Poly-crystalline Solar Cell \\
\hline No. Of Cells and Connections & $18 \mathrm{pcs}(2 \mathrm{x} 9)$ \\
\hline Maximum Power & $3 \mathrm{~W}$ \\
\hline Voltage at Max Power & $9 \mathrm{~V}$ \\
\hline Current at Max Power & $330 \mathrm{~mA}$ \\
\hline Open Circuit Voltage & $10.8 \mathrm{~V}$ \\
\hline Dimension & $195 \times 125 \times 3 \mathrm{~mm}$ \\
\hline Weight & $90 \mathrm{~g}$ \\
\hline
\end{tabular}

\subsection{Software Design}

This section explained the circuit design of light dependent resistor controlling the rotation of the servo motor by using Proteus software. This circuit consists of an Arduino UNO a LCD Display, a servo motor, five units of light dependent resistor (LDR), five units of $10 \mathrm{k} \Omega$ resistor, a reset button, an on/off button. The system flowchart, block diagram and circuit design of horizontal single axis solar tracking circuit has been shown in the Figure 3 and 4 respectively.

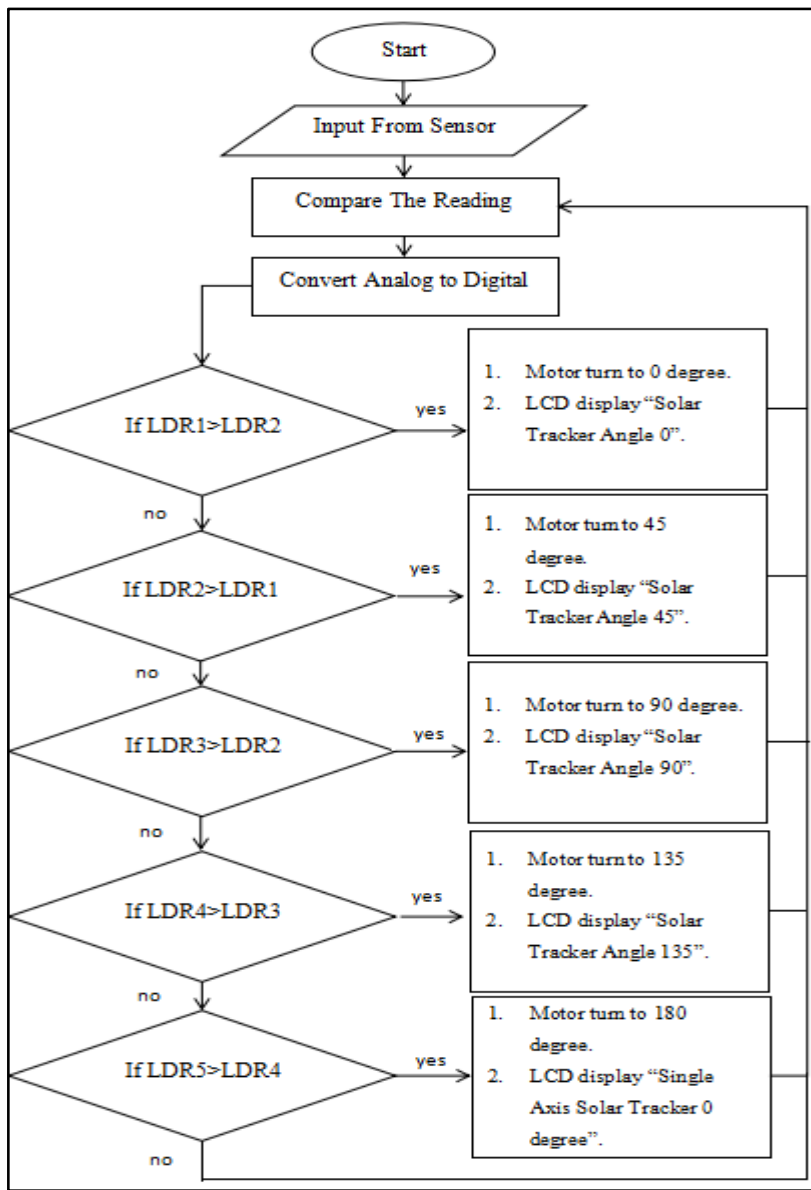

Figure 3. System Flowchart for Horizontal Single Axis Solar Tracker

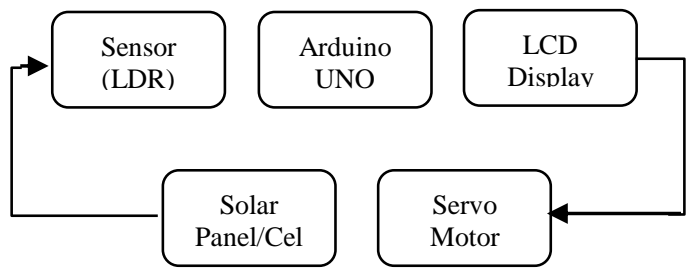

Figure 4. Block Diagram for Horizontal Single Axis Solar Tracker 


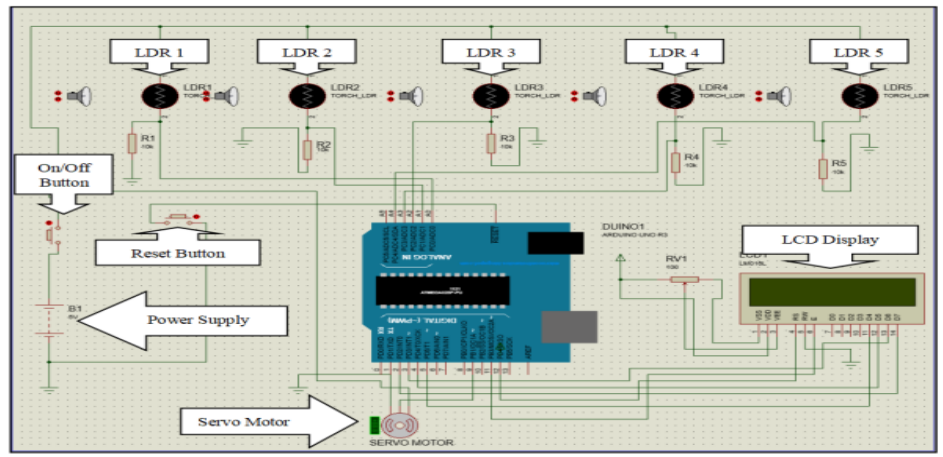

Figure 5. Circuit Design for horizontal single axis solar tracker

\subsection{Hardware Design}

This section discusses the idea on hardware design for single axis solar tracker. The drawing of this prototype hardware has been design by using the Sketch Up 3D software as shown in Figure 6 to Figure 9.

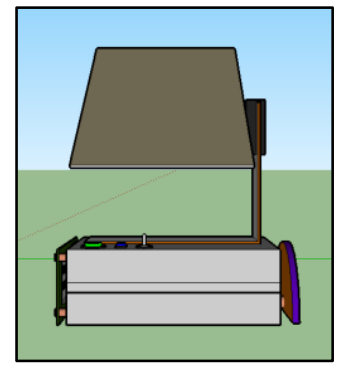

Figure 6. Front View

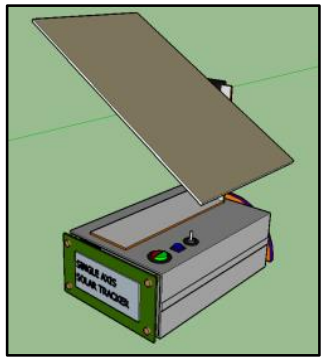

Figure 7. Isometric View

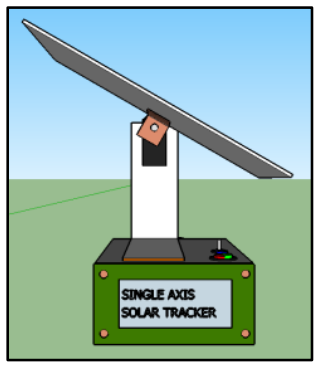

Figure 8. Side View A

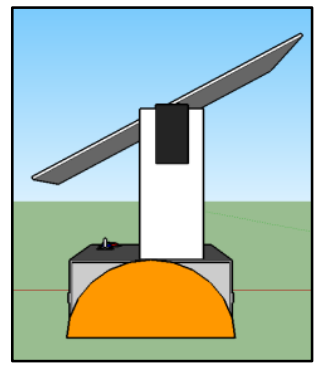

Figure 9. Side View B

\section{RESULTS AND ANALYSIS}

This section explained the result of outdoor testing. Outdoor testing has been done to show the functionality of the horizontal single axis solar tracker system towards sunlight. The outdoor testing takes place at Taman Universiti coordinated at (latitude: 1.848954, longitude: 103.0755082) on 6th December 2017 and 8th December 2017. The testing is done only if the weather is in good condition. Comparison of power, voltage, current and efficiency between static solar panel with fixed angle and solar tracker with variable angles has been taken. Data and analysis is taken from 0800 hours until 1800 hours.

\subsection{Testing with No Load}

The testing has been done on 6th December 2017 as shown in Figure 10. The data of output value from the solar panel has been recorded and tabulated in the Table 4.

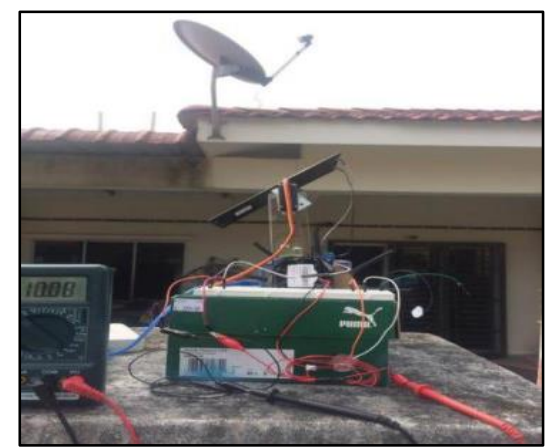

Figure 10. Testing with No Load 
Table 4. Comparison of Solar Panel Output Values between Fixed Solar Panel and Horizontal Single Axis Solar Tracker System with No Load

\begin{tabular}{|c|c|c|c|c|c|c|c|c|}
\hline \multirow{2}{*}{$\begin{array}{c}\text { Time } \\
\text { (Hours) }\end{array}$} & \multicolumn{4}{|c|}{$\begin{array}{l}\text { Solar Panel Output Values } \\
\text { with Fixed Angle }\left(90^{\circ}\right)\end{array}$} & \multicolumn{4}{|c|}{$\begin{array}{l}\text { Solar Tracker Panel Output } \\
\text { Values with Variable Angles }\end{array}$} \\
\hline & $\mathbf{A}\left({ }^{\circ}\right)$ & $\mathbf{V}(\mathbf{V})$ & I(A) & $\mathbf{P}(\mathbf{W})$ & $\mathbf{A}\left({ }^{\circ}\right)$ & $V(V)$ & I(A) & $\mathbf{P}(\mathrm{W})$ \\
\hline $8.00 \mathrm{am}$ & 90 & 9.74 & 0.04 & 0.39 & 180 & 10.11 & 0.21 & 2.12 \\
\hline $9.00 \mathrm{am}$ & 90 & 9.86 & 0.05 & 0.49 & 135 & 10.54 & 0.32 & 3.37 \\
\hline $10.00 \mathrm{am}$ & 90 & 10.11 & 0.21 & 2.12 & 135 & 10.29 & 0.28 & 2.88 \\
\hline $11.00 \mathrm{am}$ & 90 & 10.14 & 0.24 & 2.43 & 90 & 10.14 & 0.24 & 2.43 \\
\hline $12.00 \mathrm{pm}$ & 90 & 10.30 & 0.26 & 2.67 & 90 & 10.30 & 0.26 & 2.67 \\
\hline $1.00 \mathrm{pm}$ & 90 & 10.13 & 0.22 & 2.23 & 90 & 10.13 & 0.22 & 2.23 \\
\hline $2.00 \mathrm{pm}$ & 90 & 9.94 & 0.08 & 0.80 & 90 & 9.94 & 0.09 & 0.89 \\
\hline $3.00 \mathrm{pm}$ & 90 & 9.84 & 0.05 & 0.49 & 45 & 9.90 & 0.08 & 0.79 \\
\hline $4.00 \mathrm{pm}$ & 90 & 8.76 & 0.04 & 0.35 & 45 & 8.82 & 0.05 & 0.44 \\
\hline $5.00 \mathrm{pm}$ & 90 & 8.61 & 0.03 & 0.26 & 45 & 8.79 & 0.04 & 0.35 \\
\hline \multirow[t]{3}{*}{$6.00 \mathrm{pm}$} & 90 & 6.47 & 0.01 & 0.06 & 0 & 8.10 & 0.02 & 0.16 \\
\hline & \multicolumn{3}{|c|}{ Total Power } & 12.29 & \multicolumn{3}{|c|}{ Total Power } & 18.33 \\
\hline & \multicolumn{3}{|c|}{ Average Power } & 1.12 & \multicolumn{3}{|c|}{ Average Power } & 1.67 \\
\hline
\end{tabular}

Further analysis has been done on the comparison of output value: power, voltage and current between the fixed solar panel and horizontal single axis solar tracker system. The result of the comparison of output value with no load is shown in the Figure 11 to Figure 13.

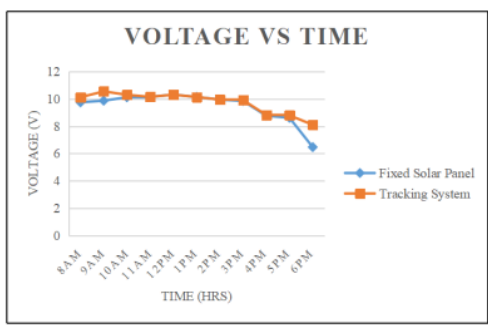

Figure 11. Voltage vs Time Graph

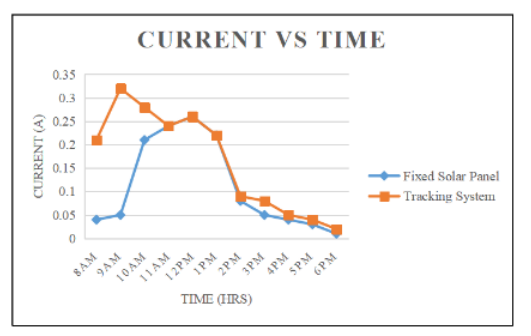

Figure 12. Current vs Time Graph

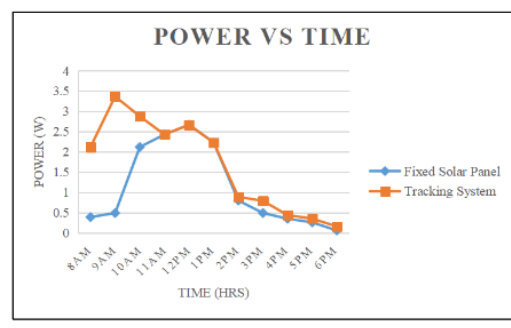

Figure 13. Power vs Time Graph

From the observation from Figure 11 and Figure 12, voltage and current value measured by solar tracking system are higher compare to the fixed solar panel. The measured value is higher because the servo motor rotates the panel perpendicularly directed towards the direction of the sunlight. Therefore, total surface areas of solar panel for solar tracker system to absorb the sunlight is much bigger compare to fixed solar panel and produce more output value. However, the value of voltage and current measured slightly decrease due to cloud shading effect. From Figure 13, indicates that the power produce by solar panel from solar tracking system higher compare to fixed solar panel. Power produce is calculated using the formula, $\mathrm{P}=\mathrm{IV}$ Equation (1).

$$
\text { Power }(\text { Watt })=\text { Current }(\text { Ampere }) \times \text { Voltage }(\text { Volt })
$$

Overall, it shows that solar tracking system able to receive more sunlight and generate more power compare to fixed solar panel. The efficiency of the system increase by $49.11 \%$ when implemented with the tracking mechanism. Efficiency of the overall system with the tracker can be calculated using the Equation (2).

$$
\text { Efficiency }=\frac{\text { AveragePower } r_{\text {tracking }}-\text { AveragePower }_{\text {fixed }}}{\text { AveragePower } r_{\text {fixed }}} \times 100 \%
$$




\subsection{Testing with Load}

The testing has been done on 8th December 2017 as shown in Figure 14. The data of output value from the solar panel has been recorded and tabulated in the Table 5.

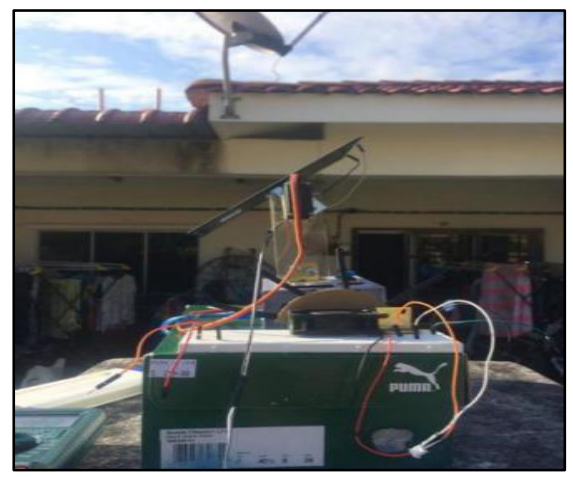

Figure 14. Testing with Load

Table 5. Comparison of Solar Panel Output Values between Fixed Solar Panel and Horizontal Single Axis Solar Tracker System with Load

\begin{tabular}{|c|c|c|c|c|c|c|c|c|}
\hline \multirow{2}{*}{$\begin{array}{c}\text { Time } \\
\text { (Hours) }\end{array}$} & \multicolumn{3}{|c}{$\begin{array}{c}\text { Solar Panel Output Values } \\
\text { with Fixed Angle (90 }\end{array}$} & \multicolumn{3}{c|}{$\begin{array}{c}\text { Solar Tracker Panel Output } \\
\text { Values with Variable Angles }\end{array}$} \\
\cline { 2 - 10 } & $\mathbf{A}\left({ }^{\circ}\right)$ & $\mathbf{V}(\mathbf{V})$ & $\mathbf{I}(\mathbf{A})$ & $\mathbf{P}(\mathbf{W})$ & $\mathbf{A}\left({ }^{\circ}\right)$ & $\mathbf{V}(\mathbf{V})$ & $\mathbf{I}(\mathbf{A})$ & $\mathbf{P}(\mathbf{W})$ \\
\hline $8.00 \mathrm{am}$ & 90 & 8.58 & 0.08 & 0.69 & 180 & 9.09 & 0.08 & 0.72 \\
\hline $9.00 \mathrm{am}$ & 90 & 8.97 & 0.08 & 0.72 & 135 & 9.13 & 0.08 & 0.73 \\
\hline $10.00 \mathrm{am}$ & 90 & 9.09 & 0.08 & 0.73 & 135 & 9.20 & 0.08 & 0.74 \\
\hline $11.00 \mathrm{am}$ & 90 & 9.24 & 0.08 & 0.74 & 90 & 9.24 & 0.08 & 0.74 \\
\hline $12.00 \mathrm{pm}$ & 90 & 9.48 & 0.08 & 0.76 & 90 & 9.48 & 0.08 & 0.76 \\
\hline $1.00 \mathrm{pm}$ & 90 & 9.37 & 0.08 & 0.75 & 90 & 9.37 & 0.08 & 0.75 \\
\hline $2.00 \mathrm{pm}$ & 90 & 8.99 & 0.08 & 0.72 & 90 & 9.09 & 0.08 & 0.72 \\
\hline $3.00 \mathrm{pm}$ & 90 & 8.48 & 0.08 & 0.68 & 45 & 8.53 & 0.08 & 0.69 \\
\hline $4.00 \mathrm{pm}$ & 90 & 8.36 & 0.08 & 0.67 & 45 & 8.65 & 0.08 & 0.69 \\
\hline $5.00 \mathrm{pm}$ & 90 & 8.69 & 0.08 & 0.70 & 45 & 8.80 & 0.08 & 0.71 \\
\hline $6.00 \mathrm{pm}$ & 90 & 6.98 & 0.08 & 0.56 & 0 & 7.56 & 0.08 & 0.60 \\
\hline & \multicolumn{3}{|c|}{ Total Power } & 7.73 & \multicolumn{3}{c|}{ Total Power } & 7.85 \\
\cline { 2 - 8 } Average Power & 0.70 & \multicolumn{6}{c|}{ Average Power } & 0.71 \\
\hline
\end{tabular}

Further analysis has been done on the comparison of output value: power, voltage and current between the fixed solar panel and horizontal single axis solar tracker system. The result of the comparison of output value with load is shown in the Figure 15 to Figure 117.

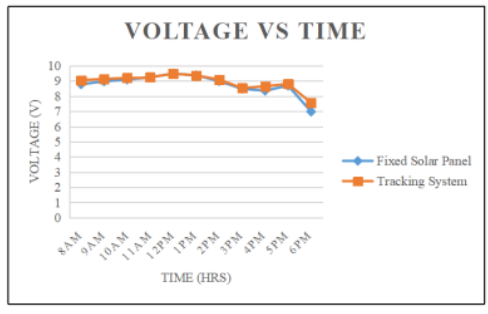

Figure 15. Voltage vs Time Graph

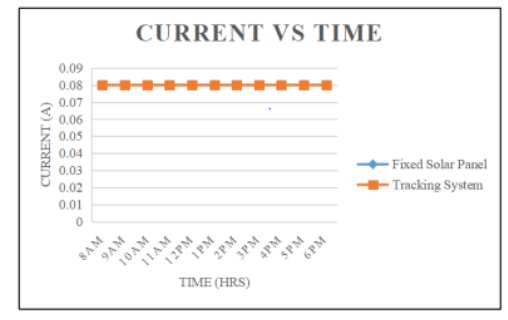

Figure 16. Current vs Time Graph

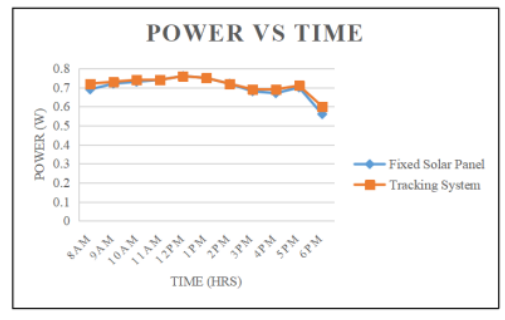

Figure 17. Power vs Time Graph

For the observation, Figure 15 and Figure 16, value of voltage measured for solar tracking system are higher compare to the fixed solar panel. The voltage measured from solar tracking system is higher because the servo motor rotate the panel perpendicularly directed towards the direction of the sunlight. Solar panel will absorb more sunlight. However, the value of voltage measured slightly decrease due to cloud 
shading effect. For the current measurement, current flow in the circuit is $0.08 \mathrm{~A}$ for both fixed and tracking system. The measurement of current constant all the time due to the existence of the load. From Figure 17, indicates that the power produce by solar panel from solar tracking system higher compare to fixed solar panel. Overall, solar tracking system receives more sunlight and generates more voltage and power compare to fixed solar panel. The efficiency of the system increase by $1.43 \%$ when implemented with the tracking mechanism. Efficiency of the overall system for on load test lesser than no load test because of the load that have been used to limit the current in the circuit.

\section{FUTURE WORK}

Firstly, the quality of having a solid, almost unyielding structure should be put as one of the main characteristics of a solar tracker. Hard and solid material need to be used as the main material for the solar tracker structure in order to withstand extreme weather condition such as strong windy day. Secondly, build a solar tracker that can be monitored from long range, by adding Global System for Mobile Communication (GSM) or build an application software. Lastly, maximizing the solar-system energy production and produce more energy by upgrading the single axis solar tracker to dual axis solat tracker. More power means a greater return on the solar investment, and greater energy savings.

\section{CONCLUSION}

An application of solar tracker using arduino approach has been presented in this study. As a conclusion, firstly the development of tracking system to control and monitor the movement of solar panel based on the intensity of the light is achieved. The solar panel will face the sun perpendicularly to absorb more solar energy. Secondly, solar tracking systems generate more output during the hours while fixed solar panel installation generates least power. However, shading effect give a slightly impact for solar panel to produce the output value. Thirdly, the percentage efficiency of the system in energy conversion increase when implemented the tracking system. The efficiency gain varies significantly with altitude and the orientation of a fixed solar panel installation in the same location.

\section{ACKNOWLEDGEMENTS}

The authors would like to acknowledge the Research Management Center (RMC), Universiti Tun Hussein Onn Malysia (UTHM), Batu Pahat, Johor, Malaysia for the financial support of this search. This research is partly by RMC under the U861 (Tier 1) Grant.

\section{REFERENCES}

[1] Suruhanjaya Tenaga (Energy Commission) Malaysia Energy Statistic Handbook. 2015: 84.

[2] Aloka Reagan Otieno (2015). Solar Tracker for Solar Panel. Faculty of Engineering Department of Electrical and Information Engineering. Universiti of Nairobi.

[3] Ayushi Nitin Ingole (2016, May 24-26). Arduino based Solar Tracking System. International Conference on Science and Technology for Sustainable Development, Kuala Lumpur, Malaysia.

[4] Tiberiu Tudorache, L. K. (2010). Design of a Solar Tracker System for PV Power Plants. Acta Polytechnica Hungarica.; 7(1), 17.

[5] Gagari Deb, Arijit Bardhan Roy. Use of Solar Tracking System for Extracting Solar Energy. International Journal of Computer and Electrical Engineering, 4(1), 42-46.

[6] Muhammad Sami Sabry (2013). Determining the accuracy of solar tracker, 1-88.

[7] Sohag, H. A., Hasan, M., Khatun, M. M., \& Ahmad, M. (2015). An Accurate and Efficient Solar Tracking System Using Image Processing and LDR Sensor, (Eict), 522-527.

[8] SA Jumaat, F Mohamad, SA Zulkifli, Development of Portable Case Solar Battery Charger, Electrical and Electronic Engineering, Vol. 6 No. 4, 2016, pp. 55-61. doi: 10.5923/j.eee.20160604.01.

[9] Siti Amely Jumaat, Mohammad Hilmi Othman, Solar Energy Measurement Using Arduino, MATEC Web Conf. 150, 2018, 01007, p. 6 